\title{
Effect of Lamivudine on the Rat Pregnancy Outcome
}

\author{
Efecto de la Lamivudina en la Rata Preñada \\ "Rosana Dorsa Vieira Pontes; *Abês Mamed Amed; **Manuel Jesus Simões; \\ **** Ricardo Martins Oliveira-Filho; *Ricardo Santos Simões \& *Luiz Kulay Jr.
}

PONTES, R. D. V.; AMED, A. M.; SIMÕES, M. J.; OLIVEIRA-FILHO, R. M.; SIMÕES, R. S. \& KULAY JR., L. Effect of lamivudine on the rat pregnancy outcome. Int. J. Morphol., 23(3):205-208, 2005.

SUMMARY: Human immunodeficiency virus (HIV) infection is in growing incidence throughout the world. Due to the increasing proportion of affected women in reproductive years, the association of pregnancy with HIV infection becomes a matter of major Public Health concern. Antiretroviral drug administration turned out to be imperative during pregnancy in order to prevent the vertical transmission; accordingly, new antiretroviral drugs and anti-HIV drug associations have been tested in experimental pregnancy models before they are approved to be included in protocols for use during human pregnancy. Lamivudine is a nucleoside reverse transcriptase inhibitor currently used in association with other antiretrovirals. Since no data exist on the perinatal safety of lamivudine alone, as it is used in combination with other antiretroviral agents, and, until now, only preliminary data on the lamivudine-zidovudine combination were available, we decided to examine the gross maternal and fetal effects of lamivudine administered alone during the entire period of rat pregnancy. Forty pregnant animals were assigned at random to 4 groups (G1, G2, G3 and G4). G1 received drug vehicle; G2, G3 and G4 received daily oral doses of 5, 15 or $45 \mathrm{mg} / \mathrm{kg}$ of lamivudine, respectively. Rats were weighed on days 0, 7, 14 and 20 of pregnancy. On day 20 they were killed, their fetuses and placentas counted and weighed. The body weight gain of the rats was that normally expected for the gestation progression; no differences were noticed among the groups. In addition, no effects were observed regarding the fetal or placental number and weight, nor in the number of implantations, reabsortions, fetal or maternal deaths. In conclusion, the adverse effects reported for the lamivudine-zidovudine combination therapy may well be not due to lamivudine; further research involving a variety of strategies is needed to definitively ascertain the safety of that combination for preventing maternal-infant HIV transmission.

KEY WORDS: Lamivudine; Toxicology; Rat; Pregnancy.

\section{INTRODUCTION}

A virus identifyied by Montagnier (Barre-Sinoussi et al., 1983) and Gallo et al. (1984), present in opportunistic infections caused by Pneumocystis carinii associated to malignant neoplasies as the Kaposi's sarcoma (Gottlieb et al., 1981; Masur et al., 1981; Siegal et al., 1981), later called the human immunodeficiency virus (HIV), is the responsible for the acquired immunodeficiency syndrome, AIDS (WHO, 2002). The infection soon spread out, originating world pandemias.

In Brazil, in the first half of 1980's, like in other countries, the proportion of infected humans were about 82 men for 1 woman. This proportion fell in the 1990's down to $4: 1$ and currently the rate remains about 2.2 men for 1 woman (Brasil, 2000). Among adolescents the situation is worse. Below the age of $13 \mathrm{yr}$ the proportion of infected people is $1: 1$; for the age group 13-19 yr it is 0.8:1; during the reproductive years it is about 0.6 male for 1 female case (Brasil, 2001). Below 13 $\mathrm{yr}$, besides the other forms of HIV infection (sexual contact and blood or blood products), the prevailing form of transmission is by infected mother to infant during pregnancy, intrapartum, perinatally, or via breast milk. The maternal-fetal transmission can comprise as much as $86.1 \%$ of the cases (Brasil, 1999). However, this last form of transmission can be strongly $(70 \%)$ reduced with minimal adverse effects for both mother and fetus with the use of zidovudine during pregnancy and delivery and 6 weeks thereafter (Connor et al., 1994).

Currently, three groups of drugs are available for the treatment of the HIV infection: the nucleoside inhibitors of reverse transcriptase (zidovudine, didanosine, lamivudine, stavudine, abacavir, zalcitabine), the non-nucleoside inhibitors

* Department of Obstetrics, Federal University of São Paulo School of Medicine, São Paulo (SP), Brazil.

** Department of Morphology, Federal University of São Paulo School of Medicine, São Paulo (SP), Brazil.

*** Department of Pharmacology, Institute of Biomedical Sciences, University of São Paulo, São Paulo (SP), Brazil. 
of reverse transcriptase (nevirapine, delavirdine, efavirenz), and the protease inhibitors (indinavir, nelfinavir, ritonavir, saquinavir, amprenavir, lopinavir).

The Centers of Disease Control and Prevention (1998) recommended that pregnant women should be scheduled in the same antiretroviral protocols used for the general population, except for the first trimester (Mofenson et al., 1999).

In 2001, the French Agence Nationale de Recherches sur le SIDA 075 Study Group (Mandelbrot et al., 2001) alerted for the scarcity of data on the perinatal safety of lamivudine alone, as it was used in combination with other antiretroviral agents, and, until that year, only preliminary data on the lamivudine-zidovudine combination were available. A study of 33 children exposed to lamivudine-zidovudine in utero reported anemia and mild elevations of liver enzyme levels in more than half of the children. There have also been case reports of metabolic acidosis in pregnant women and in infants. That Study Group reported that the occurrence of anemia and neutropenia was frequent and severe in a few cases. Mitochondrial dysfunction was diagnosed in 2 children who had fatal neurologic disorders and in a third child with a persistently elevated lipase level, but the possible relation between these cases and exposure to the study drugs was controversial at that time.

Von Tungeln et al. (2002) investigated the induction of mutations and micronuclei in mice treated neonatally (from days 1-8 of age) with zidovudine (AZT), lamivudine (3TC), or a combination of the two drugs. They found that AZT and AZT/3TC, but not 3TC alone, caused a significant increase in micronuclei, with the response being greatest one day after the last dose. None of the drugs induced mutations in the Hprt gene, while AZT and AZT/3TC, but not 3TC, caused a significant increase in the $\mathrm{Tk}$ mutant frequency. These data suggested that AZT, but not 3TC, is genotoxic in neonatal mice, and that 3TC does not alter significantly the responses observed with AZT alone.

The present paper was designed to investigate the effects of lamivudine on the rat pregnancy outcome, when administered during the entire period of gestation.

\section{MATERIAL AND METHOD}

Female adult virgin, EPM-1 Wistar rats weighing 230$260 \mathrm{~g}$, under routine laboratory care were mated in the proportion of 2 females for 1 male during $2 \mathrm{~h}$. Pregnancy was verified according to Hamilton \& Wolfe (1938); the finding of spermatozoa in vagina was taken as an indication of pregnancy (day 0). Forty pregnant rats were then randomly divided into 4 groups and treated from the 1stup to the 20th day of gestation as follows. Group G1 (control), treated with drug vehicle (destilled water); groups G2, G3 and G3, groups of animals treated respectively with 5,15 or $45 \mathrm{mg} / \mathrm{kg}$ b.w. of lamivudine. Drugs and vehicle $(1 \mathrm{ml} / \mathrm{rat})$ were given once a day at 08:00 h by gavage. Body weight gain was monitored by weighing the animals at days 0,7 th, 14th and 20th of pregnancy.

At term (20th day), the animals were killed under deep ether anesthesia. Upon laparotomy and uterine horns opening, the sites of implantations and reabsorptions were recorded; the living fetuses and their placentae were carefully removed, loosely passed onto filter paper to remove excess liquid and weighed to the nearest of $0.1 \mathrm{mg}$.

Data were analysed by one-way analysis of variance and the Kruskal-Wallis' multiple comparisons test (Sokal \& Rohlf, 1969; Siegel, 1975).

\section{RESULTS AND DISCUSSION}

For antiretroviral therapy of pregnant women, therapy is deferred until the second trimester because of the potential and uncertain risk of teratogenesis and the low risk of transmission during this period. Research has also found that maternal factors including viral load, immune status, chorioamnionitis, prematurely ruptured membranes and, to a lesser extent, intravenous drug use and smoking are associated with increased vertical transmission (Loutfy \& Walmsley, 2004).

It is of interest that this drug crosses the human placenta, and at birth the plasma levels of lamivudine found in the maternal, the umbilical cord and the fetal blood are similar (Moodley et al., 1998).

Although some adverse effects of lamivudine have been reported (including nausea, vomiting, anorexia, pancreatitis, hepatotoxicity, hyperglucemia) (Hill et al., 2001), no overt signs of maternal toxicity were noticed. As seen in Table I, the body weight increase of all groups of pregnant rats was not different from that of a normal rat pregnancy development. Similarly, no interference of the treatment with lamivudine was noticed with respect to the blastocist implantation or with the maternal letality (Table II).

Regarding the fetal compartment, although the use of lamivudine is not recommended before the end of the embryonary period (Poirier et al., 2004), in our experiments we did not found any signs of reabsorption (Table II). In addition, even with the use of doses 9-fold higher than those 
used in human therapy, with about 440 fetuses studied herein we were not able to detect intrauterine deaths, or any alterations of the number or the weight of fetuses and placentae. These findings suggest that lamivudine is not associated with prematurity or low weight at birth in rats, in parallel with the results of a meta-analysis study about the risk of an adverse outcome with antiretroviral therapy during pregnancy (Tuomala et al., 2002).
In conclusion, as far as our preliminary experimental data are concerned, the adverse effects reported for the lamivudine-zidovudine combination therapy do not appear to be due to lamivudine. Although lamivudine is generally reported to be well tolerated during human pregnancy (Mirochnick \& Capparelli, 2004), further research involving a variety of strategies may be needed to definitively ascertain the safety of that combination for preventing maternal-infant HIV transmission.

Table I. Body weight gain of pregnant rats treated with lamivudine during the entire gestation. Data are given in grams (mean $\pm \mathrm{SD})$.

\begin{tabular}{ccccc}
\hline \multirow{2}{*}{ Day of gestation } & G1 & G2 & G3 & G4 \\
0 & $229.1 \pm 11.8$ & $222.1 \pm 13.9$ & $221.0 \pm 16.4$ & $226.4 \pm 21.3$ \\
7 th & $211.7 \pm 15.9$ & $234.8 \pm 15.6$ & $239.9 \pm 17.1$ & $244.1 \pm 18.9$ \\
14 th & $237.8 \pm 17.8$ & $256.6 \pm 16.5$ & $260.9 \pm 20.8$ & $261.8 \pm 18.1$ \\
2 Cth & $261.9 \pm 25.1$ & $302.7 \pm 15.2$ & $310.3 \pm 21.7$ & $298.6 \pm 19.3$ \\
\hline
\end{tabular}

Groups of pregnant animals ( $\mathrm{n}=10$ for every group) were treated once a day by gavage with destilled water $(\mathrm{G} 1=$ control) or lamivudine $(\mathrm{G} 2=5 \mathrm{mg} / \mathrm{kg} ; \mathrm{G} 3=15 \mathrm{mg} / \mathrm{kg} ; \mathrm{G} 4=45 \mathrm{mg} / \mathrm{kg})$ throughout gestation. No significant differences were noticed among the groups within each pregnancy period.

Table II. Maternal and fetal outcome of rats treated with lamivudine during the entire gestation. Data are mean \pm SD of parameters measured at term (20th day of pregnancy).

\begin{tabular}{lcccc}
\hline Parameter & $\mathrm{G} 1$ & $\mathrm{G} 2$ & Groups & $\mathrm{G} 3$ \\
Number of implantations & $10.4 \pm 1.4$ & $11.0 \pm 1.2$ & $12.7 \pm 1.1$ & $10.1 \pm 1.2$ \\
Number of resorptions & - & - & - & $0.2 \pm 0.1$ \\
Implantation/resorption rate & - & - & - & $0.01 \pm 0.001$ \\
Number of placentae & $10.4 \pm 1.4$ & $11.0 \pm 1.2$ & $12.7 \pm 1.1$ & $10.1 \pm 1.2$ \\
Fetuses alive & $10.4 \pm 1.4$ & $11.0 \pm 1.2$ & $12.7 \pm 1.1$ & $10.1 \pm 1.2$ \\
Fetal deaths & - & - & - & $0.01 \pm 0.001$ \\
Fetal weight $(\mathrm{g})$ & $3.60 \pm 2.8$ & $4.07 \pm 1.5$ & $3.88 \pm 1.8$ & $4.01 \pm 1.5$ \\
Placental weight $(\mathrm{g})$ & $0.69 \pm 0.15$ & $0.72 \pm 0.18$ & $0.64 \pm 0.21$ & $0.78 \pm 0.16$
\end{tabular}

Groups of pregnant animals $(\mathrm{n}=10$ for every group) were treated once a day by gavage with destilled water $(\mathrm{G} 1=\mathrm{control})$ or lamivudine $(\mathrm{G} 2=5 \mathrm{mg} / \mathrm{kg} ; \mathrm{G} 3=15 \mathrm{mg} / \mathrm{kg} ; \mathrm{G} 4=45 \mathrm{mg} / \mathrm{kg})$ throughout gestation. No significant differences were noticed among the groups.

PONTES, R. D. V.; AMED, A. M.; SIMÕES, M. J.; OLIVEIRA-FILHO, R. M.; SIMÕES, R. S. \& KULAY JR., L. Efecto de la lamivudina en la rata preñada. Int. J. Morphol., 23(3):205-208, 2005.

RESUMEN: La infección por el virus de la inmunodeficiencia humana (HIV) presenta incidencia creciente en todo el mundo. Debido al aumento en la proporción de mujeres afectadas en sus años reproductivos, el binomio embarazo/infección con HIV constituyen un tema preocupante en Salud Pública. Por esto que, la administración de fármacos antirretrovirales ha sido considerada obligatoria durante la gestación para prevenir la transmisión vertical del HIV; de este modo, nuevos fármacos y combinaciones de fármacos con actividad anti-HIV han sido desarollados y testeados en modelos de preñez experimental, previo a su empleo en estrategias de terapia antirretroviral durante la gestación humana. Lamivudina es un inhibidor nucleosídico de la transcriptasa reversa usada en combinación con otros antirretrovirales, pero no hay datos sobre la seguridad de su uso aislado. En el presente trabajo son estudiados los posibles efectos de la lamivudine cuando es administrada durante toda la preñez de la rata albina. Cuarenta ratas preñadas fueron tratadas durante toda la preñez (desde el día 0 hasta el día 20 de la gestación) con 5, 15 o $45 \mathrm{mg} / \mathrm{kg}$ de lamivudina, una vez al día. Los controles recibieron el vehículo de la droga. La evolución del peso corporal de los animales fue lo esperado para la progresión normal del peso durante la preñez, sin diferencias significativas entre los grupos. Igualmente no hubo diferencias en cuanto al número de fetos y de placentas y tampoco en cuanto a sus pesos. Ningún efecto fue notado con respecto al número de implantaciones o de reabsorciones. Se concluye que los efectos adversos reportados para la combinación zidovudina-lamivudina no deben, en principio, ser atribuidos a la presencia de la lamivudina.

PALABRAS CLAVE: Lamivudina; Toxicología; Rata hembra; Preñez. 


\section{REFERENCES}

Barre-Sinoussi, F.; Cherman, J. C. \& Nugeyre, M. T. Isolation of a T-lymphotropic retrovirus from a patient at risk for acquired immnune deficiency sindrome (AIDS). Science, 220: 868$71,1983$.

BRASIL. Ministério da Saúde. Bol. Epidemiol. AIDS, 14, 2001.

BRASIL. Ministério da Saúde. Epidemiologia da transmissão vertical do HIV no Brasil. http://www.aids.gov.br/udtv/ boletim-jun.ago.1999/trans-vertical.htm

BRASIL. Ministério da Saúde. Programa Nacional de DST/ AIDS. Bol. Epidemiol AIDS, 12, 2000.

CENTERS OF DISEASE CONTROL AND PREVENTION. Public Service Task Force recommendations for the use of antiretroviral drugs in pregnancy women infected with HIV1 for maternal heath and for reducing prenatal HIV-1 transmission in the United States, MMWR, 47: No RR-2, 1998.

Connor, E. M.; Sperling, R. S.; Gelber, R. \& Kiselev, P. Reduction of maternal-infant transmission of human immunodepficiency virus type 1 with zidovudine treatment. N. Engl. J. Med., 331:1173-80, 1994.

Gallo, R. C.; Salahuddin, S. Z. \& Popovic, M. Frequent detection and isolation of cytopathic retroviruses (HTLV-III_ from patients with AIDS and risk for AIDS. Science, 224: 500-3, 1984.

Gottlieb, M. S.; Schoroff, R.; Schanker, M. \& Weisman, J. D. Pneumocystis carinii pneumonia and mucosal candidiasis in previously healthy homosexual men. N. Engl. J. Med., 305: 1425-31, 1981.

Hamilton, J. B. \& Wolfe, J. M. The effect of male hormone substance upon birth and prenatal development in rat. Anat. Rec.,70:433-40, 1938.

Hill, J. B.; Sheffield, J. S.; Zeeman, G. \& Wendel, G. D. Jr. Hepatotoxicity with antiretroviral treatment of pregnant women. Obstet. Gynecol., 98:909-11, 2001.

Loutfy, M. R. \& Walmsley, S. L. Treatment of HIV infection in pregnant women: antiretroviral management options. Drugs. 64:471-88, 2004.

Mandelbrot, L.; Landreau-Mascaro, A.; Rekacewicz, C.; Berrebi, A.; Benifla, J. L.; Burgard, M.; et al. Lamivudine-zidovudine combination for prevention of maternal-infant transmission of HIV-1. JAMA, 285:2083-93, 2001.

Masur, H.; Michelis, M.A.; Greene, J. B. \& Onorato, I. An outbreak of community-acquired Pneumocystis carinii pneumonia. N. Engl, J. Med., 305:1431-8, 1981.

Mirochnick, M. \& Capparelli, E. Pharmacokinetics of antiretrovirals in pregnant women. Clin. Pharmacokinet., 43: 1071-87, 2004.

Mofenson, L. M.; Lambert, J. S. \& Stiehm, E. R. For the pediatric AIDS clinical trials group study 185 team. Risk factors for perinatal transmission of human deficiency virus type 1 in women treated with zidovudine. N. Engl. J. Med., 341:38593, 1999.

Moodley, J.; Moodley, D. \& Pillay, K. Pharmacokinetics and antiretroviral activity of lamivudine alone or when coadministered with zidovudine in human immunodeficieny virus type 1 - infected pregnant woman and their offspring. J. Infect. Dis., 178:1327-33, 1998.

Poirier, M.C.; Olivero, O.A.; Walker, D.M. \& Walker, V.E. Perinatal genotoxicity and carcinogenicity of anti-retroviral nucleoside analog drugs. Toxicol. Appl. Pharmacol., 199:151-61, 2004.

Siegal, F. P.; Lopez, C. \& Hammer, G. S. Severe acquired immunodeficiency in male homosexuals, manifested by chronic perinatal ulcerative herpes simplex lesions, N. Engl. J. Med., 305:1439-44, 1981.

Siegel, S. Estadística no paramétrica. Trilla, México, 1975.

Sokal, R. R. \& Rohlf, F. J. Biometry. WH Freeman, San Francisco, 1969.

Tuomala, R.E.; Shapiro, D. E. \& Mofenson, L.M. Antiretroviral therapy during pregnancy and the risk of an adverse outcome. N. Engl. J. Med., 346:1863-70, 2002.

Von Tungeln, L.S.; Hamilton, L.P.; Dobrovolsky, V.N.; Bishop, M.E.; Shaddock, J.G.; Heflich, R.H. et al. Frequency of Tk and Hprt lymphocyte mutants and bone marrow micronuclei in $\mathrm{B} 6 \mathrm{C} 3 \mathrm{~F}(1) / \mathrm{Tk}+/$ - mice treated neonatally with zidovudine and lamivudine. Carcinogenesis, 23:1427-32, 2002.

WORLD HEALTH ORGANIZATION. AIDS, epidemic update. December 2002 http://www.unaids.org/worldaidsday/2002/ press/update/epiupdate-2002-en.doc

Correspondence to:

Dra. Rosana Dorsa Vieira Pontes

Rua Pernambuco, 946, Apart. 1.203

São Francisco

CEP 79010-040

Campo Grande-MS Received: 28-03-2005

BRASIL
Accepted: 06-06-2005 